\title{
24. Studies on the Host Range of Hop Stunt Disease in Japan
}

\author{
By Matsuo SASAKI*) and Eishiro ShIKATA**)
}

(Communicated by Teikichi FukUshI, M. J. A., June 14, 1977)

Most of Japanese commercial hop plants (Humulus lupulus L. cv. Kirin II) are contaminated with either ring and band pattern mosaic like disease or hop latent virus (Inoue, 1971, 1973a and b) and frequently with both of them. In addition, hop stunt disease has been distributed throughout the hop gardens in the northern part of the mainland of Japan.

Hop stunt disease (HSD) was first described by Yamamoto et al. (1970 and 1973) and recognized as a virus disease based on graft and sap transmission. Diseased hop plants (HSD hop plants) show mainly shortened internodes of the main and lateral bines with curled upper leaves, and consequently they become strikingly stunted (Fig. 1). Their cone yields are reduced to at least a half of those obtained from "HSD-free" hop plants, which appeared free from HSD symptoms, but may be contaminated with those two diseases mentioned above. Among the bitter substances in cones from HSD hop plants, alpha-acid content decreases to one half or one third of HSD-free ones (Yamamoto et al., 1973).

As the hop ( $H$. lupulus) and $H$. japonicus Sieb. et Zucc. are the only known hosts with long incubation periods of 2-3 years and more than 3 months, respectively, experimental works with this disease are greatly limited owing to the lack of suitable indicator plants.

In this note we will describe the results of sap transmission experiments to several other plant families, which proved that cucurbitaceous plants are susceptible to the disease under consideration.

Materials and methods. HSD hop plants were collected at several hop gardens in Fukushima and Iwate Prefectures and HSDfree hop plants in Fukushima and Yamanashi Prefectures in April, 1976. Young shoots of HSD hop plants grown in a green house were cut and macerated in three volumes $(\mathrm{w} / \mathrm{v})$ of $0.1 \mathrm{M}$ phosphate buffer at $\mathrm{pH}$ 7.0. Young seedlings of 40 species and cultivars including Cucurbitaceae, Moraceae, Leguminosae, Chenopodiaceae, Solanaceae,

\footnotetext{
*) The Research Laboratories of Kirin Brewery Co., Ltd., Miyahara-cho, Takasaki, Japan.

**) Department of Botany, Faculty of Agriculture, Hokkaido University, Sapporo, Japan.
} 

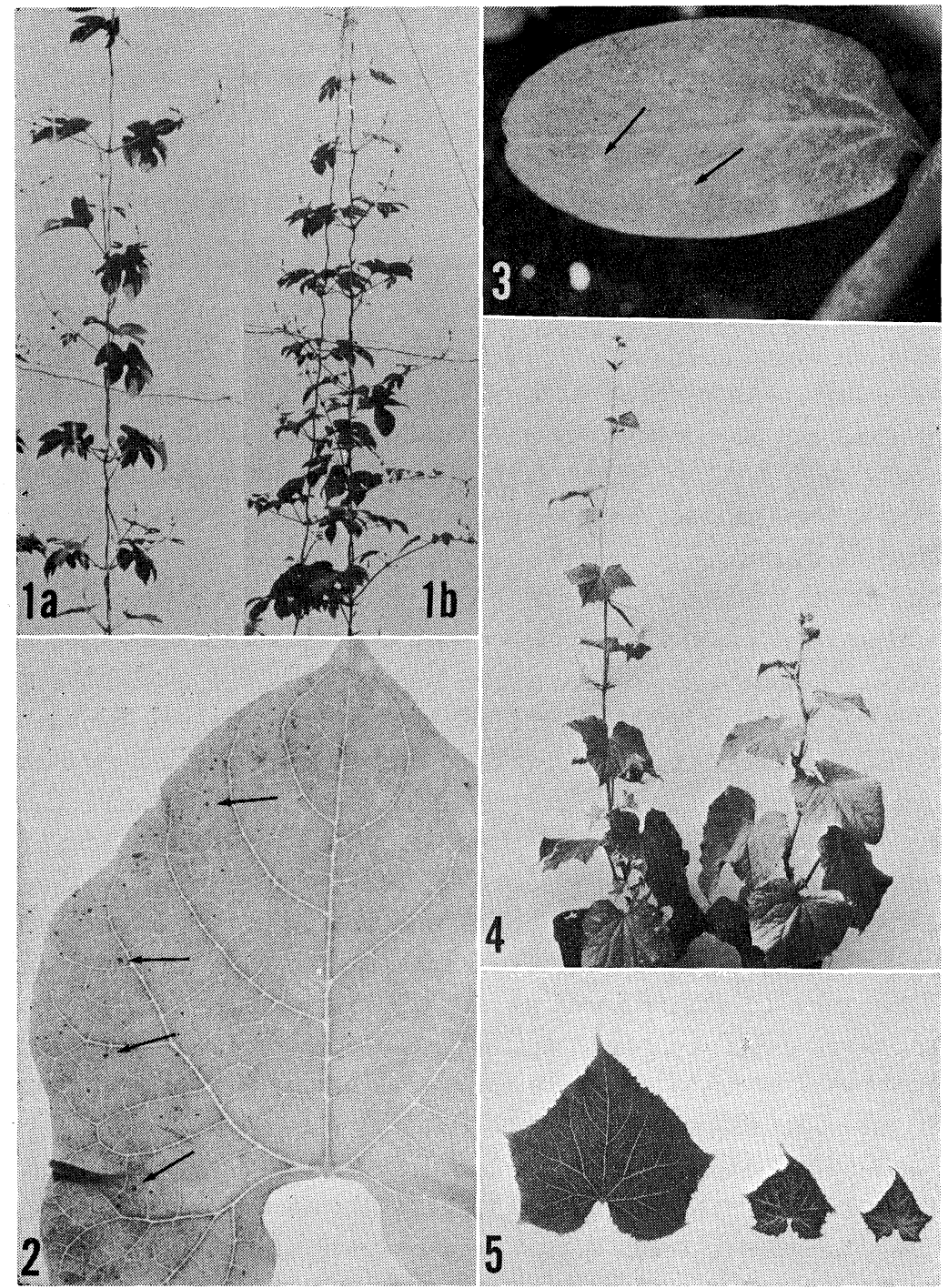

Figs. 1-5. Fig. 1a: HSD-free hop plant (H. lupulus cv. Kirin II) in July. Fig. 1b: Symptoms of HSD hop plants (cv. Kirin II) in July, showing shortened internodes and curled upper leaves. Fig. 2: Necrotic local lesions (arrows) on a primary leaf of $P$. vulgaris induced by hop latent virus. Fig. 3: Chlorotic ring spots (arrows) on a cotyledon of a cucumber plant (C. sativus cv. Suhyoh). These spots were caused by the inoculation with the sap from either HSD or HSD-free hop plants. Fig. 4: Symptoms of a cucumber plant (cv. Suhyoh) affected with hop stunt disease (right) showing shortened internodes, as compared with a healthy plant (left). Fig. 5: Small and rugose leaves showing vein clearing (middle and right) of an HSD-infected cucumber plant and a healthy leaf (left). 


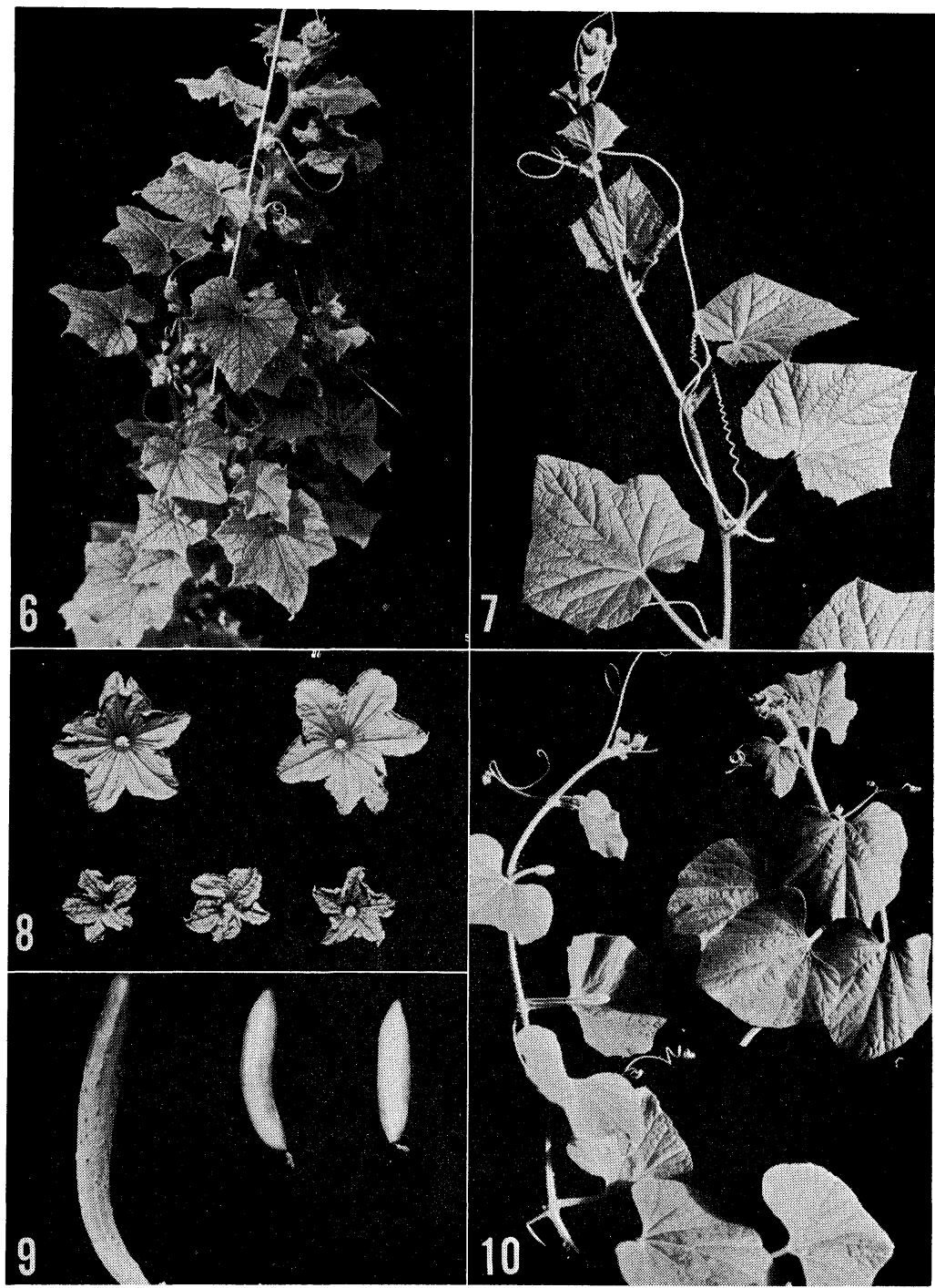

Figs. 6-10. Fig. 6: Symptoms of a cucumber plant (cv. Aonaga-jibai) two months after inoculation with the sap from HSD hop plants, showing shortened internodes and interveinal chlorosis. Fig. 7: A healthy cucumber plant (cv. Aonaga-jibai) after two months, as a control of Fig. 6. Fig. 8: Small and crumpled flowers (bottom) of a cucumber plant (cv. Suhyoh) affected with HSD and healthy flowers (upper). Fig. 9: Small and pale fruits (middle and right) of a cucumber plant (cv. Kagaaonagafushinari) affected with HSD and a healthy fruit (left). Fig. 10: Symptoms of $L$. siceraria var. clavata (right) showing shortened internodes and leaf curl, and a healthy control plant (left). Note that these two plants have the same number of internodes. 
Tetragonia expansa Murr., Gomphrena globosa L., Vinca rosea L., Sesamum indicum L. and Pharbitis nil Chois. were inoculated with crude saps from HSD hop plants with carborundum. Crude saps from HSD-free hop plants were also used as controls, because there were possibilities that HSD hop plants were contaminated with other viruses. The inoculated seedlings were grown in a green house at about $22-28^{\circ} \mathrm{C}$ and observed for more than 30 days.

Results. The inoculated plants of Chenopodiaceae, Solanaceae, Tetragonia expansa, Gomphrena globosa, Vinca rosea, Sesamum indicum and Pharbitis nil showed no symptom 30 days after inoculation. However, plants of Cucurbitaceae, Phaseolus vulgaris and $H$. japonicus proved to be susceptible (Table I). Necrotic local lesions

Table I. Sap transmission experiments

\begin{tabular}{|c|c|c|c|c|}
\hline \multirow{3}{*}{ Plant species } & \multicolumn{4}{|c|}{ Symptoms* } \\
\hline & \multicolumn{2}{|c|}{$\begin{array}{l}\text { Inocula from HSD } \\
\text { hop plants }\end{array}$} & \multicolumn{2}{|c|}{$\begin{array}{l}\text { Inocula from HSD- } \\
\text { free hop plants }\end{array}$} \\
\hline & $\begin{array}{l}\text { Inoculated } \\
\text { leaves }\end{array}$ & $\begin{array}{l}\text { Systemic } \\
\text { infection }\end{array}$ & $\begin{array}{c}\text { Inoculated } \\
\text { leaves }\end{array}$ & $\begin{array}{l}\text { Systemic } \\
\text { infection }\end{array}$ \\
\hline Cucumis sativus & $\operatorname{CS}(5 / 15)^{* *}$ & VC, S $(15 / 15)$ & CS (5/15) & $-(0 / 15)$ \\
\hline C. melo (Spicy) & $-(0 / 5)$ & $\mathrm{C}, \mathrm{S}(2 / 5)$ & $-(0 / 5)$ & $-(0 / 5)$ \\
\hline $\begin{array}{l}\text { Lagenaria siceraria var. } \\
\text { clavata (Daimaru) }\end{array}$ & $-(0 / 9)$ & $\mathrm{C}, \mathrm{S}(4 / 9)$ & $-(0 / 4)$ & $-(0 / 4)$ \\
\hline $\begin{array}{l}L . \text { siceraria var. } \\
\text { microcarpa }\end{array}$ & $-(0 / 4)$ & C, S $(3 / 4)$ & $-(0 / 4)$ & $-(0 / 4)$ \\
\hline $\begin{array}{l}\text { Phaseolus vulgaris } \\
\text { (Taisho-kintoki) }\end{array}$ & NL (6/6) & $-(0 / 6)$ & $\mathrm{NL}(6 / 6)$ & $-(0 / 6)$ \\
\hline$($ Toiku D-4)*** & $\mathrm{NL}$ & - & NL & - \\
\hline Humulus japonicus & $-(0 / 14)$ & $\mathrm{S}(3 / 14)$ & $-(0 / 7)$ & $-(0 / 7)$ \\
\hline
\end{tabular}

were produced on the primary leaves of $P$. vulgaris (Fig. 2) and chlorotic ring spots on cucumber cotyledons (Fig. 3) when they were inoculated with inocula from both HSD and HSD-free hop plants. It was assumed that the necrotic local lesions on bean leaves were caused by hop latent virus, which could be revealed by the electron microscope in dip preparations negatively stained with 2\% PTA. The nature of virus which produced chlorotic ring spots on cucumber cotyledons was unknown. When cucumber cotyledons were inoculated with crude saps from upper leaves of HSD-infected cucumber plants, no symptom appeared.

The other symptom appeared on cucurbitaceous plants was remarkable stunting of the whole plants. The infected cucumber 
plants (Cucumis sativus L.) produced small and rugose upper leaves with vein clearing, and shortened internodes (Figs. 4 and 5). The infected leaves showed clear interveinal chlorosis more than two months later (Figs. 6 and 7). The flowers were small in size with crumpled petals (Fig. 8) and the fruits became small in size and pale or almost white in color (Fig. 9). Those fruits seldom developed.

Cucumis melo L., Lagenaria siceraria Standl. var. clavata Hara and $L$. siceraria var. microcarpa Hara also became stunted showing curled upper leaves 30-50 days after inoculation (Fig.10). The affected plants of $L$. siceraria var. clavata eventually died after 50 days. H. japonicus plants also were stunted showing shortened internodes three months after inoculation. The re-inoculation of cucumber plants from the affected plants of $C$. melo, L. siceraria var. clavata and microcarpa, and $H$. japonicus induced the same symptoms.

All cucumber plants inoculated with the sap from 10 HSD hop plants were stunted whereas no plants became diseased when inoculated with the sap from $9 \mathrm{HSD}$-free hop plants (Table II). Chlorotic ring spots appeared on cucumber cotyledons when crude saps from very young shoots of both HSD and HSD-free hop plants were inoculated.

Table II. Sap inoculation experiments to cucumber plants

\begin{tabular}{|c|c|c|c|c|}
\hline \multirow{2}{*}{ Localities } & \multicolumn{2}{|c|}{$\begin{array}{c}\text { Inocula from HSD } \\
\text { hop plants }\end{array}$} & \multicolumn{2}{|c|}{$\begin{array}{l}\text { Inocula from HSD- } \\
\text { free hop plants }\end{array}$} \\
\hline & $\begin{array}{l}\text { CS* on } \\
\text { cotyledons }\end{array}$ & $\begin{array}{l}\text { Systemic } \\
\text { infection } \\
\text { (stunting) }\end{array}$ & $\begin{array}{l}\text { CS on } \\
\text { cotyledone }\end{array}$ & $\begin{array}{l}\text { Systemic } \\
\text { infection } \\
\text { (stunting) }\end{array}$ \\
\hline Fukushima & $3 / 9 * *$ & $9 / 9$ & $4 / 6$ & $0 / 6$ \\
\hline Iwate & $0 / 1$ & $1 / 1$ & - & - \\
\hline Yamanashi & - & - & $0 / 3$ & $0 / 3$ \\
\hline Total & $3 / 10$ & $10 / 10$ & $4 / 9$ & $0 / 9$ \\
\hline
\end{tabular}

When nine cucumber cultivars were inoculated, the symptoms which were observed on Suhyoh, Aonaga-jibai, Kinsei-suhyoh, Kurosango, Kamekoh-shunjuh, and Kaga-aonagafushinari showed similar appearance about 30 days after inoculation. Pickles I and II, however, became affected after longer incubation periods showing moderate symptoms. At higher temperature or at about $30^{\circ} \mathrm{C}$, symptoms began on cucumber plants earlier than those placed at around $25^{\circ} \mathrm{C}$.

Discussion. From the above results, it is most likely that the stunting of cucumber plants was caused by the HSD agent. The counter-inoculation tests from the affected cucumber plants to HSD- 
free hop plants are under way to ascertain whether the agent in affected cucumber plants is the same as HSD agent. But it will take at least 2-3 years until it will be proved (Yamamoto et al., 1973).

It is very interesting to note that the symptoms on cucumber plants and host range of this disease are quite similar to those of the cucumber pale fruit disease in Europe, which was suggested to be a viroid-induced disease by Van Dorst and Peters (1974), though no experimental proof was presented.

Acknowledgments. The authors thank Dr. T. Fukushi, Emer. Prof., Hokkaido Univ., and Dr. M. Inoue, Kanagawa Pref. Pub. Health Lab., for their helpful advice.

\section{References}

1) Inoue, M., and Murayama, D. (1971): Ann. Phytopath. Soc. Japan, 37, 411.

2) - (1973): Ibid., 39, 154.

3) Inoue, M., Shikata, E., and Murayama, D. (1973) : Ibid., 39, 220.

4) Yamamoto, H., et al. (1970) : Mem. Fac. of Agr., Hokkaido Univ., 7, 491-515.

5) - (1973): Rept. Res. Lab. Kirin Brewery Co., Ltd., 16, 49-62.

6) Van Dorst, H. J. M., and Peters, D. (1974): Neth. J. Pl. Path., 80, 85-96. 